\title{
Effect of growth hormone on human alveolar macrophage oxidative metabolism
}

\author{
M P Keane, R Coakley, R Costello, S J O’Neill
}

\begin{abstract}
Background - Growth hormone (GH) has diverse immunological actions and has been shown to augment oxidative metabolism in rat peritoneal and porcine alveolar macrophages and both human and animal neutrophils. A study was performed to determine the effects of GH on human alveolar macrophages in vitro. Methods - Macrophages were harvested from 10 patients undergoing bronchoalveolar lavage and incubated with 0,10 and $100 \mathrm{nmol} / \mathrm{ml} \mathrm{GH}$ for four hours. Oxidative metabolism was assessed by means of a fluorescent assay using FMLP and $E$ coli as stimulants. Fluorescence was measured using flow cytometry.

Results - No difference in basal or stimulated oxidative metabolism was found between the GH and control groups.

Conclusions - GH does not have a direct stimulatory action on human alveolar macrophages in vitro. However, this does not exclude an indirect effect in vivo. The results contrast with previous studies on animal alveolar macrophages.

(Thorax 1997;52:818-819)
\end{abstract}

Keywords: growth hormone, human alveolar macrophages, oxidation.

Human leucocytes have been shown to synthesise growth hormone $(\mathrm{GH}),{ }^{1}$ and $\mathrm{GH}$ and its growth promoting peptide insulin-like growth factor (IGF)-1 have diverse immunological actions. ${ }^{2}$ Normal thymic and lymphoid cells have binding sites for $\mathrm{GH}$ and prolactin. ${ }^{3} \mathrm{GH}$ primes human neutrophils via the prolactin (PRL) receptor. ${ }^{4}$ Porcine alveolar macrophages and rat alveolar and peritoneal macrophages show augmented superoxide response to GH. ${ }^{2}$ The cytolytic potential of natural killer (NK) cells is also effected by GH and, indeed, NK cells from $\mathrm{GH}$-deficient children have an intrinsic defect compared with healthy controls in that they fail to respond to interferon. ${ }^{5}$ A beneficial role for $\mathrm{GH}$ in malnourished patients with chronic obstructive pulmonary disease has also been suggested. ${ }^{6}$

This study was undertaken to determine the effect of $\mathrm{GH}$ on human alveolar macrophage oxidative metabolism and to see if the findings in animal studies could be demonstrated in humans.

\section{Methods}

Alveolar macrophages were harvested from 10 normal healthy male volunteers by means of bronchoalveolar lavage according to standard guidelines. Lavage fluid was centrifuged at $250 \mathrm{~g}$ for 10 minutes and the resulting pellet was resuspended in DMEM supplemented with $10 \%$ fetal calf serum and $5 \%$ penicillin and streptomycin and made up to a final concentration of $1 \times 10^{6}$ macrophages $/ \mathrm{ml}(>90 \%$ viability by trypan blue exclusion). These were then incubated with two concentrations of $\mathrm{GH}$ $(10 \mathrm{nmol} / \mathrm{ml}$ and $100 \mathrm{nmol} / \mathrm{ml})$ or vehicle control for four hours. The concentrations and time points were derived from concentrationresponse and time course experiments. Alveolar macrophages were assessed for oxidative metabolism using the fluorogenic substrate DHR $123 .{ }^{7}$ Briefly, $100 \mu \mathrm{l}$ of $1 \times 10^{6}$ macrophages $/ \mathrm{ml}$ were incubated under three conditions, alone, with $20 \mu \mathrm{l}$ of $1 \times 10^{-6} \mathrm{M}$ FMLP, or with $20 \mu \mathrm{l}$ opsonised $E$ coli $\left(1 \times 10^{9}\right.$ bacteria/ml $)$ for 10 minutes at $37^{\circ} \mathrm{C}$. $20 \mu \mathrm{l}$ of substrate, which is fluorescent on interaction with reactive oxygen species, was then added. FACS lysing solution ( $1 \mathrm{ml})$ was added to fix the macrophages. Samples were centrifuged, washed, resuspended in PBS, and stored at $4^{\circ} \mathrm{C}$ in the dark until FACS analysis. Immunofluorescence analysis was conducted with the use of a FACScan equipped with an argon laser providing excitation wavelength of $\lambda \mathrm{ex}=488 \mathrm{~nm}$ and collection of fluorescent signal at $\lambda \mathrm{em}=$ $530+15 \mathrm{~nm}$ (green fluorescence) and $\lambda \mathrm{em}=$ $595+30 \mathrm{~nm}$ (red fluorescence). The intensity of fluorescence was used as an indicator of oxidative metabolism.

Statistical analysis was by means of ANOVA.

\section{Results}

There was no significant difference between the control and the growth hormone groups at either concentration (fig 1).

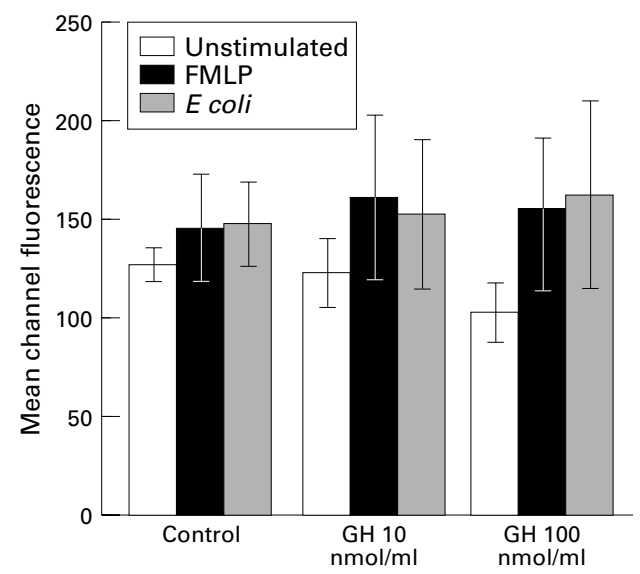

Figure 1 Effect of growth hormone (GH) on oxidative metabolism. Values are mean (SE). 


\section{Discussion}

Our results contrast with previously described results in animal macrophages. ${ }^{2}$ It is possible that the effects of $\mathrm{GH}$ on human macrophages are mediated in vivo by IGF-1 or somatomedin $\mathrm{C}$, the synthesis of both of which are stimulated by $\mathrm{GH}$. However, $\mathrm{GH}$ has been shown to prime human neutrophils directly and IGF-1 antibodies do not antagonise this effect. GH augments human granulopoiesis in vitro by inducing synthesis of somatomedin C. ${ }^{8}$ The fact that we demonstrated no increase in oxidative metabolism with $\mathrm{GH}$ stimulation rules out an effect mediated via macrophage-derived somatomedin C or IGF-1. It does not, of course, exclude a more distant paracrine mode of action in vivo.

While our method of measuring oxidative metabolism differs from the other studies on $\mathrm{GH}$, it has been previously validated. ${ }^{7}$ It measures intracellular reactive oxygen metabolite release, but it is unlikely there would be a rise in extracellular free radicals without a rise in intracellular levels.

Functional heterogeneity of diverse macrophage and $\mathrm{T}$ cell properties has been demonstrated both for intra-species populations of macrophages $^{9}$ and inter-species ${ }^{10}$ populations of $\mathrm{T}$ cells. We propose that our failure to demonstrate an augmenting effect of $\mathrm{GH}$ on human alveolar macrophage oxidative metabolism represents a further example of inter- species functional heterogeneity. In conclusion, we have shown that growth hormone fails to stimulate oxidative metabolism directly in human alveolar macrophages. This does not rule out an indirect effect in vivo.

1 Weigent DA, Baxter JB, Wear WE, Smith LR, Bost KL, Blalock JE. Production of immunoreactive growth hormone by mononuclear leukocytes. FASEB 1988;2:2812-8.

2 Kelley K. Growth hormone, lymphocytes and macrophages. Biochem Pharmacol 1989;38:705-13.

3 Kiess W, Butenandt O. Specific growth hormone receptors on human peripheral mononuclear cells: re-expression, identification and characterization. F Clin Endocrinol Metab 1985;60:740-6.

4 Fu YK, Arkins S, Fuh G, Cunningham BC, Wells JA, Fong $\mathrm{S}$, et al. Growth hormone augments superoxide anion secretion of human neutrophils by binding to the prolactin receptor. F Clin Invest 1992;89:451-7.

5 Kiess W, Malozowski S, Gelato M, Butenand O, Doerr H, Crisp B, et al. Lymphocyte subset distribution and natural killer activity in growth hormone deficiency before and during short term treatment with growth hormone releasing hormone. Clin Immunol Immunopathol 1988;48: 85-94.

6 Pape GS, Friedman M, Underwood LE, Clemmons DR The effect of growth hormone on weight gain and pulmonary function in patients with chronic obstructive lung disease. Chest 1991;99:1495-500.

7 Emmendorffer A, Hecht M, Lohmann-Matthes M, Roesler J. A fast and easy method to determine the production of reactive oxygen intermediates by human and murine phagocytes using dihydrorhodamine 123. I Immuno Methods 1990;131:269-75.

8 Merchav S, Tatarsky I, Hochberg Z. Enhancement of human granulopoiesis in vitro by biosynthetic insulin-like growth factor 1/somatomedin $\mathrm{C}$ and human growth hormone. Clin Invest 1988;81:791-7.

9 O’Neill SJ, Hoehn SK, Lesperance E, Klass DJ. Functional heterogeneity of isopycnic fractions of rat alveolar macrophages. Infect Immun 1984;46:282-4.

10 Odake S, Kam CM, Narasimhan L, Poe M, Blake JT, Krahenbuhl $\mathrm{O}$, et al. Human and murine cytotoxic $\mathrm{T}$ lymphocyte serine proteases: subsite mapping with peptide thioester substrates and inhibition of enzyme activity and
cytolysis by isocoumarins. Biochemistry 1991;30:2217-27. 